\title{
Impact of foliar application of carbon nanotube and benzyladenine on broccoli growth and head yield
}

\author{
Mohamed A.M., Mahmoud E. A., Younes N. A.* \\ Department of Horticulture, Faculty of Agriculture, Al-Azhar University, Assiut, Egypt
}

\begin{abstract}
The experiment were performed on the broccoli (Brassica oleracea var. Italica) at an a private farm in, Tema, city, Sohag, Egypt located at N 26 ${ }^{\circ} 52^{\prime} 12.1908^{\prime \prime}$, E $31^{\circ} 24^{\prime}$ during the two successive winter seasons of 2018 and 2019 respectively, to study the effect of foliar applications with carbon nanotube (CNTs), benzyladenine (BA) and the combined effect of them on vegetative growth, head yield and head quality of broccoli in a clay loam soil. CNTs at $3 \mathrm{~g} / \mathrm{L}, 5 \mathrm{~g} / \mathrm{L}$ and $7 \mathrm{~g} / \mathrm{L}$ concentrations and 50,100 and $150 \mathrm{ppm}$ of BA and the interaction of them, was sprayed on broccoli seedlings after two weeks of transplanted. A random complete block design (RCBD) with three replications was used. The data showed that positively effect of CNTs at $7 \mathrm{~g} / \mathrm{L}$ and 100 ppm of BA. Also, CNTs at $5 \mathrm{~g} / \mathrm{L}$ plus BA at $100 \mathrm{ppm}$ scored the maximum values of broccoli growth characters and flower head yield.
\end{abstract}

Keywords: carbon nanotube, benzyladenine, broccoli, Brassica oleracea .

*Corresponding author: Younes N. A., 


\section{Introduction}

Sprouting broccoli (Brassica oleracea L. var. italica) belongs to the family Brassicaceae. Broccoli is grown in very limited scattered areas in Egypt, while it is widely cultivated in many European and American countries. Broccoli has a great importance, enormous nutritional and medicinal values attributed to being vitamins, minerals, number of antioxidants which decrease the formation of cancer (Doklega and Abd El-Hady, 2017) of the case-controlled studies, 56\% demonstrate a strong association between increased broccoli consumption and the protection against cancer (Verhoeven et al., 1996). This protective effect has largely been attributed to the complement of phytochemicals, in broccoli which include the vitamins $\mathrm{C}$ and $\mathrm{E}$, the flavonols quercetin and kaempferol, the carotenoids $\beta$-carotene, lutein and the glucosinolates (Podsędek, 2007). For these reasons, the cultivation of broccoli started to spread lately where Egypt is ranking the fifteenth in the world production with a total production of 121127 tones valuing, while china is the top world producer of broccoli (FAO, 2019). Despite the growing importance of cultivating broccoli under Egyptian conditions, very little studies have been carried out on enhancing the growth and production of such crop under local agricultural conditions. For this reason, growers are playing safe by adding extra amount of fertilizers in order to avoid any possible loss in production. However, the new trend in modern agricultural production requires efficient, sustainable and environmentally sound fertilizer management practices in order to save environment and human health. Plant hormones, such as cytokinins, play a key role in the stimulation of cell division, nucleic acid metabolism, and root-shoot interactions, particularly under stress (Hare et al., 1997; Ha et al., 2012). Cytokinins are one of the five major types of plant hormones that play an important role in the cell cycle and affect the growth and development of plants. In addition to promoting cell division and plant growth and development, cytokinins also impede plant senescence by inhibiting the decomposition of chlorophyll, nucleic acids, proteins, and other substances in plants and redistributing necessary amino acids, hormones, inorganic salts, and other compounds to other parts of the plant (Yun et al., 2020). Three most commonly detected and most physiologically active cytokinins include zeatin, dihydrozeatin and isopentyladenine (IPA). Kinetin and benyladenine (BA) are highly active. Benzyladenine riboside has been extracted from petunia (Salisbury and Ross, 1990). Cytokinins (CKs) are plant hormones known to be key regulators of various aspects of plant growth and development, including cell division, leaf senescence, apical dominance, lateral root formation, stress tolerance, and nutritional signaling (Argueso et al., 2009; Sakakibara, 2006; Werner et al., 2003). Exogenous application of synthetic CKs, such as 6-benzylaminopurine (BA) and N-(2-chloro-pyridin-4-yl)-N'-phenylurea (CPPU), can induce fruit set and development in fruit crops such as grape, kiwifruit, melon, watermelon, apple, and pear (Flaishman et al., 2001; Hayata et 
al., 1995, 2000; Kim et al., 2006; Stern et al., 2003; Zabadal and Bukovac, 2006). Furthermore, endogenous levels of CKs have been linked with fruit growth (Gillaspy et al., 1993; Srivastava and Handa, 2005). Therefore, CKs may play important roles in fruit development. The mechanism of action by cytokinins varies in different tissues hence the variability of cytokinin effects. Fosket (1977) reported that cytokinins promote cell division by increasing the transition of cells from G2 to mitosis, (G2 refers to the period of cell growth after DNA replication that preceeds mitosis). Cytokinins increase the transition of cells from G2 to mitosis by increasing the rate of protein synthesis. Some of these proteins could be enzymes needed for mitosis. Stimulating formation of mRNAs that code for protein could also increase protein synthesis. Cytokinins effect seems to be specifically on translation. The ribosomes in treated cells are frequently grouped in large protein synthesizing polysomes rather than in small polysomes or as free monoribosomes characteristic of slowly dividing cells. Experimental evidence has also shown that cytokinins promote faster incorporation of radioactive amino acids into proteins and inhibition of the physiological response by inhibitors of protein synthesis. Cytokinins effect may also be as a result of their effect on the cell's osmotic potential (Bewli and Witham, 1976; Huff and Ross, 1975). In plants, endogenous CK content is known to be spatially and temporally regulated by a fine balance between synthesis and catabolism (Hirose et al., 2008). In many plant species, the initial step of CK biosynthesis is catalysed by adenosine phosphate-isopentenyltransferase producing isopentenyladenine (IPT), (iP) nucleotides as CK precursors (Kakimoto, 2001; Takei et al., 2001; Sakamoto et al., 2006). In Arabidopsis (Arabidopsis thaliana), the iP-nucleotides are converted into trans-zeatin (tZ) nucleotides by the cytochrome P450 monooxygenases, CYP735A1 and CYP735A2 (Takei et al., 2004). To become biologically active, CK nucleotides produced by IPTs and CYP735As must be converted to the freebase form. A CK-activating enzyme (LOG), which directly converts CK nucleotides to the active nucleobases, was recently identified in rice and Arabidopsis (Kurakawa et al., 2007; Kuroha et al., 2009). Inactivation of CKs occurs by degradation or conjugation, and cytokinin oxidase/dehydrogenase (CKX) catalyses the irreversible degradation of CKs in many plant species. CKX is a flavin adenine dinucleotide-containing oxidoreductase that selectively cleaves unsaturated $N^{6}$ side chains from $\mathrm{tZ}$, iP, and their corresponding ribosides and it is primarily responsible for metabolic CK inactivation (Jones and Schreiber, 1997; Mok and Mok, 2001; Werner et al., 2006). When radish cotyledons are grown in weak light, cytokinins increase the internal production of reducing sugars (mainly glucose, sucrose and fructose) and these sugars act osmotically to cause water uptake that drives growth (Bewli and Witham, 1976; Huff and Ross, 1975). Siddiqui et al. (2011) estimated that treatments with 10 and $15 \mathrm{ppm}$ 6benzylaminopurine can be used to extend shelf life of fresh-cut broccoli florets during storage at $6 \pm 1^{\circ} \mathrm{C}$ at commercial level. Another study 
conducted by Siddiqui et al. (2015b) reported that 6benzylaminopurine (BAP) with $200 \mathrm{ppm}$ and $300 \mathrm{ppm}$ can be used to increase quality and enhanced antioxidant activity of cauliflower upto 12 days at 25oC. In his study, fresh cauliflower curds were treated with 6benzylaminopurine at three concentrations $(100,200$, or $300 \mathrm{ppm} \mathrm{w/v)} \mathrm{and} \mathrm{its}$ effects on lipid peroxidation, membrane integrity, bioactive molecules, antioxidant activity, soluble sugar, etc. were observed during storage at ambient conditions. BAP profoundly delayed lipid peroxidation and loss of membrane integrity of the tissue, which was associated with the ageing and senescence processes. A positive effect of BAP on maintaining higher bioactive molecules (ascorbic acid and total phenols), antioxidant activity, and soluble sugar was also observed at 200 and $300 \mathrm{ppm}$, which was decreased in control curds. Therefore, $200 \mathrm{ppm}$ BAP is recommended for practical application considering the cost of 6benzylaminopurine. Dandan et al. (2018) observed that 6-BAP significantly inhibited decay incidence of harvested litchi, associated with a direct inhibition on Peronophythora litchii, the major pathogenic fungi and also reduced $\mathrm{H} 2 \mathrm{O} 2$ accumulation and lipid peroxidation, which may account for browning inhibition to an extent and higher contents of anthocyanin and total phenolic compounds. Furthermore, higher activities of SOD, CAT and APX and DPPH radical scavenging capacity in BAP-treated fruit possibly benefited reducing ROS accumulation and lipid peroxidation. Overall, application of BAP showed great potential to control decay and browning and extend shelf life of harvested litchi. The field of nanotechnology has gained increased attention and has quickly intensified over the years due to its unique properties and diverse applications in different fields of science and technology. Different kinds of nanomaterials and their applications have been introduced; however, among them, carbon-based nanomaterials, including graphite, diamond, fullerene, graphene, and carbon nanotubes (CNTs), have been extensively studied. CNTs are widely used in plant sciences (Phytonanotechnology), which alter conventional plant production systems, detoxify chemicals (pesticides and fertilizers), increase disease resistance, and act as plant growth regulators (Anuradha et al., 2020). New promising applications, like nano fertilizers, could handle cultivation in poor desert conditions. Nanofertilizers are nanomaterials which contain nanoparticles having unique physicochemical properties, i.e., large surface area, high reactivity, compatible pore size and particle morphology (Giraldo et al., 2014). They provide one or more nutrients to plants for improving their growth and yields. They have high efficiency and consequently reduce the undesirable environmental effects that result from the massive usage of conventional fertilizers (Lahiani et al., 2013). Nanofertilizers such as nanophosphorus-fertilizer, nano-calcium carbonate, iron, magnesium, manganese, zinc, molybdenum oxides (Siddiqui et al., 2015b) were investigated on plants and many of them showed positive responses 
according to the concentration used. Otherwise, Carbon nanotubes (CNTs) could be used as a nutrient carrier for macro and micro elements that may reduce their higher concentrations which are usually used. Carbon nanotubes applications in agriculture showed very promising results (Liu and Lal, 2015). It takes an important role due to its competitive mechanical, electrical, thermal and chemical properties (Siddiqui et al., 2015a). Single and multi-walled CNTs special properties could be benefit for researches in the field of agriculture and food. Recently, some researches had shown that carbon nanotubes treatment encouraged growth, branching and other aspects of plant growth parameters. Multi-walled CNTs might act as regulators for seed germination and growth or could organize the marker genes to enhance cell culture growth by increasing cell divisions, cell wall formation and water transport. It was found that CNTs can penetrate coat of tomato seeds and induce germination and growth (Khodakovskaya et al., 2009; 2012). In addition, the engineered CNTs could induce germination of seed, growth and development of plants (Siddiqui and Al-Whaibi, 2014). However, in some researches, multi-walled CNTs did not found to show a positive effect on seed germination in many plants (Husen and Siddiqi, 2014; Lin and Xing, 2007). Some other studies faced the potential toxicity of multi-walled CNTs in plant cells (Lin et al., 2009; Stampoulis et al., 2009; Tan et al., 2009; Tan and Fugetsu, 2007). This could be due to the higher concentrations used or the sensitivity of some plants or some of their growth stages in those investigations (Taha et al., 2016). Recently, the in vitro effect of CNTs on date palm cultures was studied (Taha et al., 2016). It was indicated that CNTs increased callus fresh weight while decreased the number of embryos compared with the control. However, germinated embryos number increased and a significant enhancement of shoot length and leaf number in elongation stage was observed. Moreover, root number, root length, plantlet length and hairy roots were enhanced. It was found that CNTs could organize nutrients absorption in the plant. They increased nitrogen, phosphorus, potassium and calcium while decreased sodium percent. Consequently, it increased total chlorophyll $\mathrm{a}$ and $\mathrm{b}$. More knowledge about nanofertilizers in agriculture and the relationships between physicochemical characteristics of nano materials and biological interactions are necessity, but also more care about the risk with handling nano particles application in this important field is needed (Taha, 2016). Scientific research is increasingly needed to study the effect of nanofertilizers on plant and their effect on human and animals' health. CNTs have been used in the agriculture, more specifically, for the growth of the plants. However, results revealed mixed effects of CNTs on plants. It improves the biomass of the plant; however, it creates acute cytotoxicity and genetic alteration in many plants (Mukherjee et al. 2016). So, the goal of the present study was to illustrate the influence of CNTs, BA and the combined effect on vegetative growth and head yield as safe tool increase broccoli productivity. 


\section{Materials and methods}

\subsection{Experimental site}

The experiment were performed on the broccoli (Brassica oleracea var. iltalica) at an a private farm in, Tema, City, Sohag, Egypt located at $\mathrm{N} 26^{\circ} 52^{\prime}$
12.1908", E $31^{\circ} 24^{\prime}$ during the two successive winter seasons of 2018 and 2019 respectively, to study the effect of foliar applications with carbon nanomaterials and benzyladenine on vegetative growth, head yield and head quality of broccoli in a clay loam soil as presented in Table (1).

Table (1): The physical and chemical properties of the samples taken from experimental soil during the two cultivated seasons.

\begin{tabular}{|l|l|l|l|}
\hline Characteristic & Value & Characteristic & Value \\
\hline O.M. $(\%)$ & 0.0062 & $\mathrm{Mg}^{+2}(\%)$ & 0.036 \\
\hline $\mathrm{CaCO}_{3}(\%)$ & 1.62 & $\mathrm{Na}^{+}(\%)$ & 6.5 \\
\hline Sand $(\%)$ & 55.2 & $\mathrm{~K}^{+}(\%)$ & 0.035 \\
\hline Silt $(\%)$ & 20.8 & Available $(\mathrm{ppm})$ & --- \\
\hline Clay $(\%)$ & 24 & $\mathrm{NH}_{4}(\%)$ & 48.0 \\
\hline Texture class & Sand clay loam & $\mathrm{N}(\%)$ & 0.032 \\
\hline pH & 7.4 & $\mathrm{P}(\%)$ & 0.0054 \\
\hline EC (dS/m) & 2.4 & $\left.\mathrm{Zn}(\%)^{+}\right)$ & 2.5 \\
\hline $\mathrm{Cl}$ & 0.355 & $\mathrm{Ca}^{+2}(\%)$ & 0.03 \\
\hline
\end{tabular}

\subsection{Experimental materials}

Carbon nanotube as a form of carbon nanomaterial was obtained from Scientific and Technological Applications Unit, Al-Azhar University (Assuit Branch), Assuit, Egypt. Also, benzyladenine were obtained from $\mathrm{Al}$ Gomhoria Company, Assuit, Egypt. The commercial Waltham $29 \mathrm{cv}$. of broccoli (importer Mecca TRADE Co. as PETO SEED product, USA) was used. The seedlings were initially grown in a greenhouse and fertilized with 19: 19: 19 for N: P: K soluble fertilizers. Seedlings (about 35 days old) were transplanted in rows $(80 \mathrm{~cm}$ apart with an intra-row spacing of $60 \mathrm{~cm}$ ). During the plantgrowing period, furrow irrigation was used. Insecticide was applied to avoid crop damage by cabbage worms and aphids. Weeds were kept under control manually.

\subsection{Experimental design}

A random complete block design (RCBD) with three replications was used. The seedlings were initially grown in a greenhouse and fertilized with 19: 19: 19 for $\mathrm{N}$ : P: K soluble fertilizers. Seedlings (about 35 days old) were transplanted in rows $(80 \mathrm{~cm}$ apart with an intra-row spacing of $60 \mathrm{~cm}$ ). Each plot size consisted of six rows with each row being $3.5 \mathrm{~m}$ long. During the plantgrowing period, furrow irrigation was used. Insecticide was applied to avoid 
crop damage by cabbage worms and aphids. Weeds were kept under control manually.

\subsection{Experimental treatments}

The experimental treatments are explained and described in the following paragraph and Table (2). Carbon nanotube treatments: Freshly prepared Carbon nanotube (CNTs) were dissolved in distilled water at the rate of $\left(\mathrm{T}_{1}\right) 3,\left(\mathrm{~T}_{2}\right)$
5 and $\left(\mathrm{T}_{3}\right) 7$ CNTs $\mathrm{g} \mathrm{L}^{-1}$. Benzyladenine treatments: Stock solution of Benzyladenine was prepared as follow: added $1000 \mathrm{mg}$ of benzyladenine to a $1000 \mathrm{ml}$ volumetric flask to obtain a final concentration of $1000 \mathrm{ppm}$, then added $2-5 \mathrm{ml}$ of $1 \mathrm{~N} \mathrm{NaOH}$ to dissolve the powder with stirring to completely dissolved, then added 50, 100 or $150 \mathrm{ml}$ of the stock solution to 1 liter of distilled water to obtain a final concentration of (T4) 50, (T5) 100 and (T6) 150 ppm.

Table (2): Carbon nanotube (CNTs) and benzyladenine (BA) treatments.

\begin{tabular}{|l|l|l|l|}
\hline Treatment code & Treatment & Carbon nanotube $(\mathrm{CNTs}) \mathrm{g} / \mathrm{L}$ & Benzyladenine (BA) (ppm) \\
\hline $\mathrm{T}_{0}$ & $\mathrm{~T}_{0}$ & 0.0 & 0.0 \\
\hline $\mathrm{T}_{1}$ & $\mathrm{~T}_{1}$ & 3 & 0.0 \\
\hline $\mathrm{T}_{2}$ & $\mathrm{~T}_{2}$ & 5 & 0.0 \\
\hline $\mathrm{T}_{3}$ & $\mathrm{~T}_{3}$ & 7 & 0.0 \\
\hline $\mathrm{T}_{4}$ & $\mathrm{~T}_{4}$ & 0.0 & 50 \\
\hline $\mathrm{T}_{5}$ & $\mathrm{~T}_{5}$ & 0.0 & 100 \\
\hline $\mathrm{T}_{6}$ & $\mathrm{~T}_{6}$ & 0.0 & 150 \\
\hline $\mathrm{T}_{7}$ & $\left(\mathrm{~T}_{1} \times \mathrm{T}_{4}\right)$ & 3 & 50 \\
\hline $\mathrm{T}_{8}$ & $\left(\mathrm{~T}_{1} \times \mathrm{T}_{5}\right)$ & 3 & 100 \\
\hline $\mathrm{T}_{9}$ & $\left(\mathrm{~T}_{1} \times \mathrm{T}_{6}\right)$ & 3 & 150 \\
\hline $\mathrm{T}_{10}$ & $\left(\mathrm{~T}_{2} \times \mathrm{T}_{4}\right)$ & 5 & 50 \\
\hline $\mathrm{T}_{11}$ & $\left(\mathrm{~T}_{2} \times \mathrm{T}_{5}\right)$ & 5 & 100 \\
\hline $\mathrm{T}_{12}$ & $\left(\mathrm{~T}_{2} \times \mathrm{T}_{6}\right)$ & 5 & 150 \\
\hline $\mathrm{T}_{13}$ & $\left(\mathrm{~T}_{3} \times \mathrm{T}_{4}\right)$ & 7 & 50 \\
\hline $\mathrm{T}_{14}$ & $\left(\mathrm{~T}_{3} \times \mathrm{T}_{5}\right)$ & 7 & 100 \\
\hline $\mathrm{T}_{15}$ & $\left(\mathrm{~T}_{3} \times \mathrm{T}_{6}\right)$ & 7 & 150 \\
\hline
\end{tabular}

Mixture treatments: The mixture treatments were $\mathrm{T} 7 \quad(\mathrm{~T} 1 \times \mathrm{T} 4), \mathrm{T} 8$ (T1×T5), T9 (T1×T6), T10 (T2×T4), T11

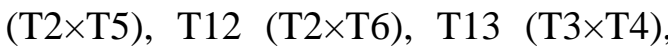

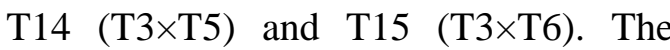
control plants were sprayed with distilled water (T0). Carbon nanotube (CNTs), benzyladenine (BA), mixture (CNTs+ BA) and control treatments were applied as foliar spray after seven days from transplanting broccoli seedlings. The spraying was conducted once a week until the appearance of floral primordia.

\subsection{Agricultural operations}

At soil preparation time, the full dose of triple superphosphate $\left(\mathrm{P}_{2} \mathrm{O}_{5}\right) 200 \mathrm{Kg}$ 
$/$ feddan $\quad\left(\right.$ feddan $=4200 \mathrm{~m}^{2}=$ 0.420 hectares $=1.037$ acres $)$ and $20 \mathrm{~m} 3$ of farmyard manure (FYM) per feddan, were added. Nitrogen fertilizer in the form of ammonium sulfate $(20.6 \%)$ and potassium in the form of potassium sulphate $\left(48 \% \mathrm{~K}_{2} \mathrm{O}\right)$ was applied at the rate of 150 and $100 \mathrm{Kg} /$ feddan respectively, of which one-third was applied at one week after transplanting of broccoli seedlings as basal dose, onethird at the early vegetative phase (30 days after transplanting) and the last onethird applied at 30 days from the previous one. All the other agricultural practices used for commercial broccoli production were carried out in this experiment (Hassan, 1991).

\subsection{Data collected}

Harvesting took place in December in the two years. The inner rows were used for sampling and harvest. Entire plants were harvested at ground level from each plot when the terminal buds were swollen but not opened. Plant height $(\mathrm{PH} \mathrm{cm})$ was determined by measuring from ground level to head bottom. Number of leaves per plant (NL/P) and leave area (LA cm) was measured. The plants were then cut $20 \mathrm{~cm}$ below the top of head, which was trimmed to obtain a marketable product. Head weight (HW g), head diameter was measured across the widest part of head (HD cm), as well as Heads yield as ton per feddan (HY ton /feddan).

\subsection{Statistical analysis}

The analysis of variance of the data was carried out on the mean values of the tested treatments according to the procedures described by Gomez and Gomez (1984). The least significant differences (LSD) at 5\% levels were used for testing the significance of the differences among the mean values of the tested treatments for each character.

\section{Results}

The following chapter shows the effect of applying CNTs, BA and interactions effect on vegetative growth, head traits and head yield of broccoli crop. Data of plant height in $\mathrm{cm}$ are presented in Table (3). Results revealed that, nonsignificantly effect of CNTs and BA concentration treatments on broccoli plant height. Broccoli plant height was increased with increasing of CNTs concentrations. Meanwhile, $100 \mathrm{ppm}$ of BA scored the highest values of plant height compared the control treatment and the other BA concentrations in both successive seasons of 2018 and 2019. Significant interactions were detected between CNTs and BA concentration treatments. Broccoli plants at CNTs 5 $\mathrm{g} / \mathrm{L}+\mathrm{BA} 100 \mathrm{ppm}\left(\mathrm{T}_{11}\right)$ treatment recorded the longest plants than the other treatments followed by CNTs $7 \mathrm{~g} / \mathrm{L}+\mathrm{BA}$ $100 \mathrm{ppm}\left(\mathrm{T}_{14}\right)$ in both seasons, respectively. 
Table (3): Effect of CNTs and BA foliar application treatments on broccoli plant height $(\mathrm{PH} \mathrm{cm})$ of 2018 and 2019 cultivated seasons.

\begin{tabular}{|c|c|c|}
\hline Treatment & 2018 & 2019 \\
\hline $\mathrm{T}_{0}$ (Control) & 68.03 & 66.13 \\
\hline $\mathrm{T}_{1}(\mathrm{CNTs} 3 \mathrm{~g} / \mathrm{L})$ & 67.80 & 65.87 \\
\hline $\mathrm{T}_{2}(\mathrm{CNTs} 5 \mathrm{~g} / \mathrm{L})$ & 69.27 & 66.87 \\
\hline $\mathrm{T}_{3}(\mathrm{CNTs} 7 \mathrm{~g} / \mathrm{L})$ & 72.47 & 69.87 \\
\hline LSD 0.05 & NS & NS \\
\hline $\mathrm{T}_{4}(\mathrm{BA} 50 \mathrm{ppm})$ & 68.13 & 65.53 \\
\hline $\mathrm{T}_{5}(\mathrm{BA} 100 \mathrm{ppm})$ & 72.80 & 69.48 \\
\hline $\mathrm{T}_{6}(\mathrm{BA} 150 \mathrm{ppm})$ & 68.80 & 68.07 \\
\hline LSD 0.05 & NS & NS \\
\hline $\mathrm{T}_{7}(\mathrm{CNTs} 3 \mathrm{~g} / \mathrm{L})+(\mathrm{BA} 50 \mathrm{ppm})$ & 68.80 & 66.87 \\
\hline $\mathrm{T}_{8}(\mathrm{CNTs} 3 \mathrm{~g} / \mathrm{L})+(\mathrm{BA} 100 \mathrm{ppm})$ & 71.40 & 71.33 \\
\hline $\mathrm{T}_{9}(\mathrm{CNTs} 3 \mathrm{~g} / \mathrm{L})+(\mathrm{BA} 150 \mathrm{ppm})$ & 70.40 & 72.40 \\
\hline $\mathrm{T}_{10}(\mathrm{CNTs} 5 \mathrm{~g} / \mathrm{L})+(\mathrm{BA} 50 \mathrm{ppm})$ & 72.80 & 72.53 \\
\hline $\mathrm{T}_{11}(\mathrm{CNTs} 5 \mathrm{~g} / \mathrm{L})+(\mathrm{BA} 100 \mathrm{ppm})$ & 85.60 & 86.80 \\
\hline $\mathrm{T}_{12}(\mathrm{CNTs} 5 \mathrm{~g} / \mathrm{L})+(\mathrm{BA} 150 \mathrm{ppm})$ & 72.73 & 75.20 \\
\hline $\mathrm{T}_{13}(\mathrm{CNTs} 7 \mathrm{~g} / \mathrm{L})+($ BA $50 \mathrm{ppm})$ & 83.53 & 84.07 \\
\hline $\mathrm{T}_{14}(\mathrm{CNTs} 7 \mathrm{~g} / \mathrm{L})+(\mathrm{BA} 100 \mathrm{ppm})$ & 84.33 & 86.33 \\
\hline $\mathrm{T}_{15}(\mathrm{CNTs} 7 \mathrm{~g} / \mathrm{L})+(\mathrm{BA} 150 \mathrm{ppm})$ & 83.33 & 84.73 \\
\hline LSD 0.05 & 5.61 & 6.65 \\
\hline
\end{tabular}

Meanwhile, CNTs $3 \mathrm{~g} / \mathrm{L}+\mathrm{BA} 50 \mathrm{ppm}$ treatment $\left(\mathrm{T}_{7}\right)$ scored the shortest plants in both seasons, respectively. Nonsignificant affect was obtained from the data which, presented in Table (4) for the leaves number per plant as affected by CNTs and BA concentration treatments in both cultivated seasons of 2018 and 2019. A slight increase of leaves number/plant was detected with increasing of CNTs concentrations. Also, BA treatment at the middle concentration $(100 \mathrm{ppm})\left(\mathrm{T}_{5}\right)$ scored the same slight increment in both seasons of 2018 and 2019. The interaction effect showed that, highly effect of CNTs and BA concentration treatments on leaves number/plant. CNTs $5 \mathrm{~g} / \mathrm{L}+\mathrm{BA} 100$ ppm $\left(\mathrm{T}_{11}\right)$ and CNTs $7 \mathrm{~g} / \mathrm{L}+\mathrm{BA} 100$ ppm $\left(\mathrm{T}_{14}\right)$ scored the maximum number of leaves per plant in both seasons of 2018 and 2019, respectively, with nonsignificant between them. It is revealed from the Table (5) that the maximum broccoli leave area in $\mathrm{cm}$ was recorded with CNTs at $7 \mathrm{~g} / \mathrm{L} \quad\left(\mathrm{T}_{3}\right)$ in both cultivated seasons. Also, BA at $100 \mathrm{ppm}$ $\left(\mathrm{T}_{5}\right)$ scored the maximized leave area than the lowest and highest BA concentrations. Significant increase in leave area were found by spraying CNTs $5 \mathrm{~g} / \mathrm{L}+\mathrm{BA} 100 \mathrm{ppm}\left(\mathrm{T}_{11}\right)$ followed by CNTs $7 \mathrm{~g} / \mathrm{L}+\mathrm{BA} 100 \mathrm{ppm}\left(\mathrm{T}_{14}\right)$, in the tow cultivated seasons of 2018 and 2019 respectively. On the other hand, CNTs 3 $\mathrm{g} / \mathrm{L}+\mathrm{BA} 150 \mathrm{ppm}\left(\mathrm{T}_{9}\right)$ scored the lowest values of leave area in $\mathrm{cm}$ in both seasons. 
Table (4): Effect of CNTs and BA foliar application treatments on broccoli number of leaves per plant (NL/P) of 2018 and 2019 cultivated seasons.

\begin{tabular}{|c|c|c|}
\hline Treatment & 2018 & 2019 \\
\hline $\mathrm{T}_{0}(\mathrm{Control})$ & 20.95 & 21.07 \\
\hline $\mathrm{T}_{1}(\mathrm{CNTs} 3 \mathrm{~g} / \mathrm{L})$ & 23.40 & 22.27 \\
\hline $\mathrm{T}_{2}(\mathrm{CNTs} 5 \mathrm{~g} / \mathrm{L})$ & 23.20 & 22.40 \\
\hline $\mathrm{T}_{3}(\mathrm{CNTs} 7 \mathrm{~g} / \mathrm{L})$ & 23.80 & 22.80 \\
\hline LSD 0.05 & NS & NS \\
\hline $\mathrm{T}_{4}(\mathrm{BA} 50 \mathrm{ppm})$ & 21.60 & 21.67 \\
\hline $\mathrm{T}_{5}(\mathrm{BA} 100 \mathrm{ppm})$ & 22.80 & 21.87 \\
\hline $\mathrm{T}_{6}(\mathrm{BA} 150 \mathrm{ppm})$ & 22.13 & 20.22 \\
\hline LSD 0.05 & NS & NS \\
\hline $\mathrm{T}_{7}(\mathrm{CNTs} 3 \mathrm{~g} / \mathrm{L})+($ BA $50 \mathrm{ppm})$ & 22.07 & 22.33 \\
\hline $\mathrm{T}_{8}(\mathrm{CNTs} 3 \mathrm{~g} / \mathrm{L})+(\mathrm{BA} 100 \mathrm{ppm})$ & 22.07 & 22.13 \\
\hline $\mathrm{T}_{9}(\mathrm{CNTs} 3 \mathrm{~g} / \mathrm{L})+(\mathrm{BA} 150 \mathrm{ppm})$ & 21.80 & 21.37 \\
\hline $\mathrm{T}_{10}(\mathrm{CNTs} 5 \mathrm{~g} / \mathrm{L})+($ BA $50 \mathrm{ppm})$ & 22.13 & 22.93 \\
\hline $\mathrm{T}_{11}(\mathrm{CNTs} 5 \mathrm{~g} / \mathrm{L})+(\mathrm{BA} 100 \mathrm{ppm})$ & 24.86 & 25.27 \\
\hline $\mathrm{T}_{12}(\mathrm{CNTs} 5 \mathrm{~g} / \mathrm{L})+(\mathrm{BA} 150 \mathrm{ppm})$ & 24.07 & 24.00 \\
\hline $\mathrm{T}_{13}(\mathrm{CNTs} 7 \mathrm{~g} / \mathrm{L})+($ BA $50 \mathrm{ppm})$ & 23.40 & 23.67 \\
\hline $\mathrm{T}_{14}(\mathrm{CNTs} 7 \mathrm{~g} / \mathrm{L})+($ BA $100 \mathrm{ppm})$ & 24.47 & 25.27 \\
\hline $\mathrm{T}_{15}(\mathrm{CNTs} 7 \mathrm{~g} / \mathrm{L})+(\mathrm{BA} 150 \mathrm{ppm})$ & 23.93 & 23.40 \\
\hline LSD 0.05 & 1.05 & 1.90 \\
\hline
\end{tabular}

Table (5): Effect of CNTs and BA foliar application treatments on broccoli leave area $(\mathrm{LA} \mathrm{cm})$ of 2018 and 2019 cultivated seasons.

\begin{tabular}{|c|c|c|}
\hline Treatment & 2018 & 2019 \\
\hline $\mathrm{T}_{0}$ (Control) & 526.14 & 583.35 \\
\hline $\mathrm{T}_{1}(\mathrm{CNTs} 3 \mathrm{~g} / \mathrm{L})$ & 592.13 & 532.85 \\
\hline $\mathrm{T}_{2}(\mathrm{CNTs} 5 \mathrm{~g} / \mathrm{L})$ & 615.83 & 571.23 \\
\hline $\mathrm{T}_{3}(\mathrm{CNTs} 7 \mathrm{~g} / \mathrm{L})$ & 621.91 & 622.33 \\
\hline LSD 0.05 & 61.94 & 56.91 \\
\hline $\mathrm{T}_{4}(\mathrm{BA} 50 \mathrm{ppm})$ & 623.17 & 565.50 \\
\hline $\mathrm{T}_{5}$ (BA $\left.100 \mathrm{ppm}\right)$ & 726.70 & 663.15 \\
\hline $\mathrm{T}_{6}$ (BA $\left.150 \mathrm{ppm}\right)$ & 645.44 & 540.53 \\
\hline LSD 0.05 & 61.94 & 56.91 \\
\hline $\mathrm{T}_{7}(\mathrm{CNTs} 3 \mathrm{~g} / \mathrm{L})+(\mathrm{BA} 50 \mathrm{ppm})$ & 639.40 & 624.17 \\
\hline $\mathrm{T}_{8}(\mathrm{CNTs} 3 \mathrm{~g} / \mathrm{L})+($ BA $100 \mathrm{ppm})$ & 659.91 & 663.89 \\
\hline $\mathrm{T}_{9}(\mathrm{CNTs} 3 \mathrm{~g} / \mathrm{L})+(\mathrm{BA} 150 \mathrm{ppm})$ & 600.15 & 577.70 \\
\hline $\mathrm{T}_{10}(\mathrm{CNTs} 5 \mathrm{~g} / \mathrm{L})+(\mathrm{BA} 50 \mathrm{ppm})$ & 685.83 & 666.24 \\
\hline $\mathrm{T}_{11}(\mathrm{CNTs} 5 \mathrm{~g} / \mathrm{L})+(\mathrm{BA} 100 \mathrm{ppm})$ & 813.93 & 871.69 \\
\hline $\mathrm{T}_{12}(\mathrm{CNTs} 5 \mathrm{~g} / \mathrm{L})+(\mathrm{BA} 150 \mathrm{ppm})$ & 720.64 & 793.03 \\
\hline $\mathrm{T}_{13}(\mathrm{CNTs} 7 \mathrm{~g} / \mathrm{L})+($ BA $50 \mathrm{ppm})$ & 797.06 & 749.67 \\
\hline $\mathrm{T}_{14}(\mathrm{CNTs} 7 \mathrm{~g} / \mathrm{L})+($ BA $100 \mathrm{ppm})$ & 798.67 & 800.65 \\
\hline $\mathrm{T}_{15}(\mathrm{CNTs} 7 \mathrm{~g} / \mathrm{L})+($ BA $150 \mathrm{ppm})$ & 713.17 & 771.56 \\
\hline LSD 0.05 & 69.47 & 80.68 \\
\hline
\end{tabular}

There was significant difference between the broccoli head weight in the study
(Table 6). Application of CNTs at $3 \mathrm{~g} / \mathrm{L}$ $\left(\mathrm{T}_{1}\right), 5 \mathrm{~g} / \mathrm{L}\left(\mathrm{T}_{2}\right)$ and $7 \mathrm{~g} / \mathrm{L}\left(\mathrm{T}_{3}\right)$ treatments 
led to increasing the head weigh gradually. Meanwhile, maximum values of head weigh were observed with BA at $100 \mathrm{ppm}\left(\mathrm{T}_{5}\right)$ than the low and high BA concentrations (50 and $150 \mathrm{ppm}$ ) $\mathrm{T}_{4}$ and $\mathrm{T}_{6}$ respectively, in both seasons of 2018 and 2019. The combined effect of CNTs and BA treatments showed extreme positive values of (CNTs $5 \mathrm{~g} / \mathrm{L})+(\mathrm{BA}$ $100 \mathrm{ppm})\left(\mathrm{T}_{11}\right)$ on head weight than the other combination treatments in both seasons respectively.

Table (6): Effect of CNTs and BA foliar application treatments on broccoli head weight (HW g) of 2018 and 2019 cultivated seasons.

\begin{tabular}{|c|c|c|}
\hline Treatment & 2018 & 2019 \\
\hline $\mathrm{T}_{0}$ (Control) & 325.79 & 277.42 \\
\hline $\mathrm{T}_{1}(\mathrm{CNTs} 3 \mathrm{~g} / \mathrm{L})$ & 395.50 & 382.73 \\
\hline $\mathrm{T}_{2}(\mathrm{CNTs} 5 \mathrm{~g} / \mathrm{L})$ & 400.13 & 405.40 \\
\hline $\mathrm{T}_{3}(\mathrm{CNTs} 7 \mathrm{~g} / \mathrm{L})$ & 416.00 & 424.20 \\
\hline LSD 0.05 & 64.48 & 71.97 \\
\hline $\mathrm{T}_{4}(\mathrm{BA} 50 \mathrm{ppm})$ & 304.33 & 326.80 \\
\hline $\mathrm{T}_{5}$ (BA $\left.100 \mathrm{ppm}\right)$ & 477.87 & 366.40 \\
\hline $\mathrm{T}_{6}$ (BA $\left.150 \mathrm{ppm}\right)$ & 357.75 & 332.17 \\
\hline LSD 0.05 & 64.48 & 71.97 \\
\hline $\mathrm{T}_{7}(\mathrm{CNTs} 3 \mathrm{~g} / \mathrm{L})+(\mathrm{BA} 50 \mathrm{ppm})$ & 478.20 & 456.80 \\
\hline $\mathrm{T}_{8}(\mathrm{CNTs} 3 \mathrm{~g} / \mathrm{L})+(\mathrm{BA} 100 \mathrm{ppm})$ & 591.60 & 590.27 \\
\hline $\mathrm{T}_{9}(\mathrm{CNTs} 3 \mathrm{~g} / \mathrm{L})+(\mathrm{BA} 150 \mathrm{ppm})$ & 568.60 & 532.00 \\
\hline $\mathrm{T}_{10}(\mathrm{CNTs} 5 \mathrm{~g} / \mathrm{L})+(\mathrm{BA} 50 \mathrm{ppm})$ & 615.47 & 556.40 \\
\hline $\mathrm{T}_{11}(\mathrm{CNTs} 5 \mathrm{~g} / \mathrm{L})+(\mathrm{BA} 100 \mathrm{ppm})$ & 845.20 & 872.87 \\
\hline $\mathrm{T}_{12}(\mathrm{CNTs} 5 \mathrm{~g} / \mathrm{L})+(\mathrm{BA} 150 \mathrm{ppm})$ & 582.20 & 562.60 \\
\hline $\mathrm{T}_{13}(\mathrm{CNTs} 7 \mathrm{~g} / \mathrm{L})+($ BA $50 \mathrm{ppm})$ & 571.33 & 584.60 \\
\hline $\mathrm{T}_{14}(\mathrm{CNTs} 7 \mathrm{~g} / \mathrm{L})+(\mathrm{BA} 100 \mathrm{ppm})$ & 696.00 & 696.80 \\
\hline $\mathrm{T}_{15}(\mathrm{CNTs} 7 \mathrm{~g} / \mathrm{L})+(\mathrm{BA} 150 \mathrm{ppm})$ & 678.40 & 644.20 \\
\hline LSD 0.05 & 91.45 & 102.04 \\
\hline
\end{tabular}

On the other hand, CNTs $3 \mathrm{~g} / \mathrm{L}+\mathrm{BA} 50$ ppm $\left(\mathrm{T}_{7}\right)$ scored the lowest means of head weight in both seasons. Data presented in Table (7) exhibit the effect of sixteen proportions of CNTs and BA treatments on head diameter of broccoli (cm). Application of CNTs with increasing dos from $3 \mathrm{~g} / \mathrm{L}$ to $7 \mathrm{~g} / \mathrm{L}$ led to increasing broccoli head diameter. But, application of BA at $100 \mathrm{ppm}$ only scored the widest diameter of broccoli than the other concentrations of BA in both seasons. The results showed that there are significant differences among the treatments by interaction of CNTs application with BA in head diameter. CNTs $5 \mathrm{~g} / \mathrm{L}+\mathrm{BA} 100 \mathrm{ppm}\left(\mathrm{T}_{11}\right)$ and CNTs $7 \mathrm{~g} / \mathrm{L}+\mathrm{BA} 100$ ppm $\left(\mathrm{T}_{14}\right)$ treatments recorded the widest diameter of broccoli heads than the other interaction treatments in both cultivated seasons of 2018 and 2019. 
Table (7): Effect of CNTs and BA foliar application treatments on broccoli head diameter (HD $\mathrm{cm}$ ) of 2018 and 2019 cultivated seasons.

\begin{tabular}{|c|c|c|}
\hline Treatment & 2018 & 2019 \\
\hline $\mathrm{T}_{0}(\mathrm{Control})$ & 20.40 & 19.65 \\
\hline $\mathrm{T}_{1}(\mathrm{CNTs} 3 \mathrm{~g} / \mathrm{L})$ & 23.33 & 22.03 \\
\hline $\mathrm{T}_{2}(\mathrm{CNTs} 5 \mathrm{~g} / \mathrm{L})$ & 23.33 & 22.40 \\
\hline $\mathrm{T}_{3}(\mathrm{CNTs} 7 \mathrm{~g} / \mathrm{L})$ & 23.80 & 23.80 \\
\hline LSD 0.05 & 1.12 & 1.34 \\
\hline $\mathrm{T}_{4}(\mathrm{BA} 50 \mathrm{ppm})$ & 20.33 & 20.60 \\
\hline $\mathrm{T}_{5}(\mathrm{BA} 100 \mathrm{ppm})$ & 23.53 & 21.80 \\
\hline $\mathrm{T}_{6}(\mathrm{BA} 150 \mathrm{ppm})$ & 22.13 & 20.15 \\
\hline LSD 0.05 & 1.12 & 1.34 \\
\hline $\mathrm{T}_{7}(\mathrm{CNTs} 3 \mathrm{~g} / \mathrm{L})+($ BA $50 \mathrm{ppm})$ & 24.40 & 23.57 \\
\hline $\mathrm{T}_{8}(\mathrm{CNTs} 3 \mathrm{~g} / \mathrm{L})+(\mathrm{BA} 100 \mathrm{ppm})$ & 26.73 & 26.00 \\
\hline $\mathrm{T}_{9}(\mathrm{CNTs} 3 \mathrm{~g} / \mathrm{L})+(\mathrm{BA} 150 \mathrm{ppm})$ & 25.50 & 24.00 \\
\hline $\mathrm{T}_{10}(\mathrm{CNTs} 5 \mathrm{~g} / \mathrm{L})+($ BA $50 \mathrm{ppm})$ & 26.60 & 26.40 \\
\hline $\mathrm{T}_{11}(\mathrm{CNTs} 5 \mathrm{~g} / \mathrm{L})+(\mathrm{BA} 100 \mathrm{ppm})$ & 31.67 & 32.40 \\
\hline $\mathrm{T}_{12}(\mathrm{CNTs} 5 \mathrm{~g} / \mathrm{L})+(\mathrm{BA} 150 \mathrm{ppm})$ & 25.40 & 25.37 \\
\hline $\mathrm{T}_{13}(\mathrm{CNTs} 7 \mathrm{~g} / \mathrm{L})+($ BA $50 \mathrm{ppm})$ & 26.73 & 26.00 \\
\hline $\mathrm{T}_{14}(\mathrm{CNTs} 7 \mathrm{~g} / \mathrm{L})+($ BA $100 \mathrm{ppm})$ & 28.73 & 28.60 \\
\hline $\mathrm{T}_{15}(\mathrm{CNTs} 7 \mathrm{~g} / \mathrm{L})+(\mathrm{BA} 150 \mathrm{ppm})$ & 27.87 & 27.33 \\
\hline LSD 0.05 & 1.58 & 1.91 \\
\hline
\end{tabular}

It was very clear that there is a positive relationship between the applied concentration of CNTs, BA and interactions effect and the response of the plant in terms of head yield (ton/feddan) (Table 8). The recorded differences between treatments were significant compared to control treatment. All applied concentrations of CNTs, BA and interactions give positive and significant effect on head yield compared to control. In CNTs treatments the highest yield was observed with the maximum dos at $7 \mathrm{~g} / \mathrm{L}$ $\left(\mathrm{T}_{3}\right)$ in both seasons. While, the middle concentration of $\mathrm{BA}\left(\mathrm{T}_{5}\right)$ recorded the highest yield of broccoli head weight as ton/feddan in both seasons. Concerning the interaction effects between different proportion of CNTs and BA, the highest values of head yield per feddan were obtained from CNTs $5 \mathrm{~g} / \mathrm{L}+\mathrm{BA} 100 \mathrm{ppm}$ $\left(\mathrm{T}_{11}\right)$ followed by CNTs $7 \mathrm{~g} / \mathrm{L}+\mathrm{BA} 100$ ppm $\left(\mathrm{T}_{14}\right)$ treatment. In the same context CNTs $3 \mathrm{~g} / \mathrm{L}+$ BA 50 ppm treatment $\left(\mathrm{T}_{7}\right)$ scored the lowest head yield as ton per feddan in both seasons of 2018 and 2019. On the contrary, the control treatment $\mathrm{T}_{0}$ was significantly the lowest compared to all treatments in both cultivated seasons respectively. 
Table (8): Effect of CNTs and BA foliar application treatments on broccoli heads yield (HY ton/feddan) of 2018 and 2019 cultivated seasons.

\begin{tabular}{|c|c|c|}
\hline Treatment & 2018 & 2019 \\
\hline $\mathrm{T}_{0}(\mathrm{Control})$ & 4.57 & 3.88 \\
\hline $\mathrm{T}_{1}(\mathrm{CNTs} 3 \mathrm{~g} / \mathrm{L})$ & 5.54 & 5.36 \\
\hline $\mathrm{T}_{2}(\mathrm{CNTs} 5 \mathrm{~g} / \mathrm{L})$ & 5.60 & 5.68 \\
\hline $\mathrm{T}_{3}(\mathrm{CNTs} 7 \mathrm{~g} / \mathrm{L})$ & 6.89 & 6.23 \\
\hline LSD 0.05 & 0.76 & 0.81 \\
\hline $\mathrm{T}_{4}(\mathrm{BA} 50 \mathrm{ppm})$ & 4.26 & 4.57 \\
\hline $\mathrm{T}_{5}(\mathrm{BA} 100 \mathrm{ppm})$ & 6.69 & 6.13 \\
\hline $\mathrm{T}_{6}(\mathrm{BA} 150 \mathrm{ppm})$ & 4.84 & 4.65 \\
\hline LSD 0.05 & 0.76 & 0.81 \\
\hline $\mathrm{T}_{7}(\mathrm{CNTs} 3 \mathrm{~g} / \mathrm{L})+($ BA $50 \mathrm{ppm})$ & 6.69 & 6.38 \\
\hline $\mathrm{T}_{8}(\mathrm{CNTs} 3 \mathrm{~g} / \mathrm{L})+(\mathrm{BA} 100 \mathrm{ppm})$ & 8.28 & 8.26 \\
\hline $\mathrm{T}_{9}(\mathrm{CNTs} 3 \mathrm{~g} / \mathrm{L})+(\mathrm{BA} 150 \mathrm{ppm})$ & 8.03 & 7.44 \\
\hline $\mathrm{T}_{10}(\mathrm{CNTs} 5 \mathrm{~g} / \mathrm{L})+($ BA $50 \mathrm{ppm})$ & 8.62 & 7.75 \\
\hline $\mathrm{T}_{11}(\mathrm{CNTs} 5 \mathrm{~g} / \mathrm{L})+(\mathrm{BA} 100 \mathrm{ppm})$ & 11.83 & 12.21 \\
\hline $\mathrm{T}_{12}(\mathrm{CNTs} 5 \mathrm{~g} / \mathrm{L})+(\mathrm{BA} 150 \mathrm{ppm})$ & 8.15 & 7.88 \\
\hline $\mathrm{T}_{13}(\mathrm{CNTs} 7 \mathrm{~g} / \mathrm{L})+(\mathrm{BA} 50 \mathrm{ppm})$ & 7.91 & 8.18 \\
\hline $\mathrm{T}_{14}(\mathrm{CNTs} 7 \mathrm{~g} / \mathrm{L})+($ BA $100 \mathrm{ppm})$ & 9.72 & 9.55 \\
\hline $\mathrm{T}_{15}(\mathrm{CNTs} 7 \mathrm{~g} / \mathrm{L})+(\mathrm{BA} 150 \mathrm{ppm})$ & 9.51 & 9.15 \\
\hline LSD 0.05 & 1.11 & 1.14 \\
\hline
\end{tabular}

\section{Discussion}

The present study aimed to reduce chemical fertilizers for sweet potato plants without reducing tuberous roots Development in agricultural management is a must in order to increase production efficiency and grower income. Growers are usually playing safe by increasing the amount of added fertilizers so that decrement in crop production may not occur. Unquestionably, insufficiency of agricultural development will guide to environmental aggravation problems, particularly in low potential areas, where expansion and increased production are crucial to help renovate the fragile natural resources base. For this reason, this study is focusing on the effect of using plant hormones, such as cytokinins and new promising applications, like nano fertilizers. In recent years, the use of nanotechnology in different areas has increased. Proof of this includes the large number of studies on the application of nanomaterials, such as metal nanoparticles (NPs) and carbon nanomaterials (CNMs), including singlewalled carbon nanotubes, multi-walled carbon nanotubes (MWCNTs), graphene, and fullerenes (Jeevanandam, 2018). In addition, Plant hormones, such as cytokinins, play a key role in the stimulation of cell division, nucleic acid metabolism, and root-shoot interactions, particularly under stress (Banowetz and Ammar, 1999; Ha et al., 2012; Hare et al., 1997; Liu et al., 2020). Thus, literately both CNTs and BA have protective agents on broccoli plants. In 
this study, all plant growth parameters were positively and significantly affected. This may be due to the role of BA and/or CNTs of crop enhancement of broccoli plants. CNTs can enter the plant either by foliar route or through the root. In the foliar route, they can enter through the stomata or through the cuticle, although the entrance is greater by the cuticle due to the large area it has in the leaves compared to the stomata (Avellan, 2019). After their entry, nanomaterials (NMs) reach the tissues of the epidermis and the mesophyll where they can interact with these tissues and their structures, and later they can be translocated to the whole plant through the vascular bundles (Hubbard et al., 2020). In addition, CNTs act as elicitors in the regulation of plant growth (Patel $e t$ al., 2017), since they activate the biosynthesis of indole acetic acid and abscisic acid (Cheng et al., 2016). They also promote the expression of marker genes of cell division (CycB) and elongation of the cell wall (NtLRX1) that directly influence growth, hence productivity (Khodakovskaya et al., 2012). Martínez-Ballesta et al. (2016) showed that broccoli plants (Brassica oleracea var. italica) treated with MWCNTs significantly increased their growth under saline stress conditions. Younes et al. (2019) denoted that the activation of photosynthetic activities by graphene nanosheet (GNS) may give reason for increased growth, productivity and crop yield of pepper and eggplants. The presence of GNS inside chloroplast may act as carbon source that facilitate carbon fixation, thus induced sugar metabolism so fructose, sucrose as well as starch enhanced progressively in leaves of GNS treated plants. With regard to BA, cytokinins are substances derived from an adenine nitrogenous base. Their physiological effects on plants are related to elongation and differentiation, capacity of division, formation and activity of apical meristems, mobilization of nutrients, break of apical dominance, germination and break of seed and dormancy, induction of parthenocarpy in fruits, flowering induction and delayed senescence (Davies, 2004; Rivero et al., 2007). This indicated that the concentrations and combinations used in the present work of CNTs and/or BA were decisive in the biochemical and yield traits. Lin et al. (2009) mentioned that CNTs had physicochemical properties as molecular transporters in the cell walls of plants, which stimulated the growth of crops and promoted the metabolism of crop growth. With regard to BA, cytokinins are substances derived from an adenine nitrogenous base. Their physiological effects on plants are related to elongation and differentiation, capacity of division, formation and activity of apical meristems, mobilization of nutrients, break of apical dominance, germination and break of seed and dormancy, induction of parthenocarpy in fruits, flowering induction and delayed senescence (Davies, 2004; Rivero et al., 2007). This indicated that the 
concentrations and combinations used in the present work of CNTs and/or BA were decisive in the biochemical and yield traits. The obtained results showed that the broccoli plants under CNTs, BA and more specifically their combination had better than non-sprayed plants (Talebi, 2018). Also, Younes et al. (2019) reported similar enhancements of eggplant and pepper growth and yield characters under carbon nanoparticles known as graphene nanosheets. López et al. (2020) reported also similar induction of growth and fruit yield under the use of carbon nanotubes of tomato plants.

\section{References}

Anuradha, P., Sanjesh, T., Parul, P., Rachana, S. and Sheo, M. P. (2020), "Carbon nanotubes as plant growth regulators: impacts on growth, reproductive system, and soil microbial community", Nanomaterials in Plants, Algae and Microorganisms, Vol. 2, Academic Press, Elsevier, USA, pp. 2342.

Argueso, C. T., Ferreira, F. J. and Kieber, J. J. (2009), "Environmental perception avenues: the interaction of cytokinin and environmental response pathways", Plant, Cell and Environment, Vol. 32, pp. 11471160

Avellan, A., Yun, J., Zhang, Y., Spielman-Sun, E., Unrine, J. M., Thieme, J., Li, J., Lombi, E., Bland, G. and Lowry, G. V. (2019),
"Nanoparticle size and coating chemistry control foliar uptake pathways, translocation, and leaf-torhizosphere transport in wheat", ACS Nano, Vol. 13 No. 5, pp. 52915305.

Banowetz, G. M., Ammar, K. and Chen, D. D. (1999), "Posta thesis temperatures influence cytokinin accumulation and wheat kernel weight", Plant, Cell \& Environment, Vol. 22, pp. 309-316.

Bewli, I. S. and Witham, F. H. (1976), "Characterization of kinetin-induced water uptake by detached radish cotyledons", Botanical Gazette, Vol. 137, pp. 58-64.

Cheng, C., Zhao, X., Zhang, M. and Bai, F. (2016), "Absence of Rtt109p, a fungal-specific histone acetyltransferase, results in improved acetic acid tolerance of Saccharomyces cerevisiae", FEMS Yeast Research, Vol. 16 No. 2, Article No. fow010.

Dandan, Z., Xu, X., Zhang, Z., Jiang, G., Feng, L., Duan, X. and Jiang, Y. (2018), "6-Benzylaminopurine improves the quality of harvested litchi fruit", Postharvest Biology and Technology, Vol. 143, pp. 137-142.

Davies, P J. (2004), Plant hormones: Biosynthesis, signal transduction, action, $3^{\text {rd }}$ ed., Kluwer Academic Publishers, Dordrecht, Netherlands.

Doklega, S. M. A. and Abd El-Hady, M. A. (2017), "Impact of organic, 
mineral and bio-fertilization on broccoli", Journal of Plant Production, Vol. 8 No. 9, pp. 945951.

FAO (2009), Agricultural Data FAOSTAT, Food and Agriculture Organization of the United Nations, Rome, Italy.

Flaishman, M. A., Shargal, A. and Stern, R. A. (2001), "The synthetic cytokinin CPPU increases fruit size and yield of 'Spadona' and 'Costia' pear (Pyrus communis L.)", Journal of Horticultural Science and Biotechnology, Vol. 76, pp. 145149.

Fosket, D. E. (1977), The regulation of the plant cell cycle by cytokinin, In: Rost T. L., Gifford E.M. (eds), Mechanisms and Control of Cell Division, Dowden Hutchinson and Ross Inc, Strousberg, Pennsylvania, USA, pp. 62-91.

Gillaspy, G., Ben-David, H. and Gruissem W. (1993), "Fruits - a developmental perspective", The Plant Cell, Vol. 5, pp. 1439-1451.

Giraldo, J. P., Landry, M. P., Faltermeier, S. M., McNicholas, T. P., Iverson, N. M., Boghossian, A. A., Reuel, N. F., Hilmer, A. J., Sen, F., Brew, J. A. and Strano, M. S. (2014), "Plant nanobionics approach to augment photosynthesis and biochemical sensing", Nature Materials, Vol. 13 No. 4, pp. 400-408.

Gomez, K. A. and Gomez, A. A. (1984),
Statistical Procedures for Agricultural Research, $2^{\text {nd }}$ ed., John Wiley \& Sons Inc., New York, USA.

Ha, S., Vankova, R., YamaguchiShinozaki, K., Shinozaki, K., Tran, L. S. P. (2012), "Cytokinins: metabolism and function in plant adaptation to environmental stresses", Trends in Plant Science, Vol. 17, pp. 172-179.

Hare, P. D., Cress, W. A. and Staden, J. V. (1997), "The involvement of cytokinins in plant responses to environmental stress", Plant Growth Regulation, Vol. 23, pp. 79-103.

Hassan, A. A. (1991), Production of Vegetable Crops, $1^{\text {st }}$ ed., Arab House for Publishing and Distribution, Cairo, Egypt (in Arabic).

Hayata, Y., Niimi, Y. and Iwasaki, N. (1995), "Synthetic cytokinin-1-(2chloro-4-pyridyl)-3-phenylurea

(CPPU) promotes fruit-set and induces parthenocarpy in watermelon", Journal of the American Society for Horticultural Science, Vo. 120, pp. 997-1000.

Hayata, Y., Niimi, Y., Inoue, K., Kondo, S. (2000), "CPPU and BA, with and without pollination, affect set, growth, and quality of muskmelon fruit", HortScience, Vol.

35 , pp. 868-870.

Hirose, N., Takei, K., Kuroha, T., Kamada-Nobusada, T., Hayashi, H. 
and Sakakibara, H. (2008), "Regulation of cytokinin biosynthesis, compartmentalization and translocation", Journal of Experimental Botany, Vol. 59, 75-83.

Hubbard, J., Gent, T. C., Hoekstra, M., Emmenegger, Y., Mongrain, V., Landolt, H. P., Adamantidis, A. R. and Franken, P. (2020), "Rapid fastdelta decay following prolonged wakefulness marks a phase of wakeinertia in NREM sleep", Nature communications, Vol. 11 No. 1 , Article No. 3130.

Huff, A. K. and Ross, C. W. (1975), "Promotion of radish cotyledon enlargement and reducing sugar content by zeatin and red light", Plant Physiology, Vol. 56, pp. 429433.

Husen A.; Siddiqi KS. (2014). Carbon and fullerene nanomaterials in plant system. J Nanotechnol. 12:1-10.

Jeevanandam, J., Barhoum, A., Chan, Y. S., Dufresne, A. and Danquah, M. K. (2018), "Review on nanoparticles and nanostructured materials: history, sources, toxicity and regulations", Beilstein Journal of Nanotechnology, Vol. 9, pp. 10501074.

Jones, R. J. and Schreiber, B. M. N. (1997), "Role and function of cytokinin oxidase in plants", Plant Growth Regulation, Vol. 23, pp. 123-134.

Kakimoto, T. (2001), "Identification of plant cytokinin biosynthetic enzymes as dimethylallyl diphosphate: ATP/ADP isopentenyl transferases", Plant and Cell Physiology, Vol. 42, pp. 677-685.

Khodakovskaya, M. V., De Silva, K., Biris, A. S., Dervishi, E. and Villagarcia, H. (2012), "Carbon nanotubes induce growth enhancement of tobacco cells", ACS Nano, Vol. 6 No. 3, pp. 2128-2135.

Khodakovskaya, M., Dervishi, E., Mahmood, M., Xu, Y., Li, Z., Watanabe, F. and Biris, A. S. (2009), "Carbon nanotubes are able to penetrate plant seed coat and dramatically affect seed germination and plant growth", ACS Nano, Vol. 3 No. 10, pp. 3221-3227.

Kim, J. G., Takami, Y., Mizugami, T., Beppu, K., Fukuda, T. and Kataoka, I. (2006), "CPPU application on size and quality of hardy kiwifruit", Scientia

Horticulturae, Vol. 110, pp. 219 222.

Kurakawa, T., Ueda, N., Maekawa, M., Kobayashi, K., Kojima, M., Nagato, Y., Sakakibara, H. and Kyozuka, J. (2007), "Direct control of shoot meristem activity by a cytokininactivating enzyme", Nature, Vol. 445 , pp. 652-655.

Kuroha, T., Tokunaga, H., Kojima, M., Ueda, N., Ishida, T., Nagawa, S., Fukuda, H., Sugimoto, K. and Sakakibara, H. (2009), "Functional analyses of lonely guy cytokininactivating enzymes reveal the 
importance of the direct activation pathway in arabidopsis", The Plant Cell, Vol. 21, pp. 3152-3169.

Lahiani, M. H., Dervishi, E., Chen, J., Nima, Z., Gaume, A., Biris, A. S. and Khodakovskaya, M. V. (2013), "Impact of carbon nanotube exposure to seeds of valuable crops", ACS Applied Materials \& Interfaces, Vol. 5 No. 16, pp. 79657973.

Lin, D. and Xing, B. (2007), "Phytotoxicity of nanoparticles: Inhibition of seed germination and root growth", Environmental Pollution, Vol. 150 No. 2, pp. 243250.

Lin, S., Reppert, J., Hu, Q., Hudson, J. S., Reid, M. L., Ratnikova, T. A., Rao, A. M., Luo, H. and Ke, P. C. (2009), "Uptake, translocation, and transmission of carbon nanomaterials in rice plants", Small, Vol. 5 No. 10, pp. 1128-1132.

Liu, R. and Lal, R. (2015), "Potentials of engineered nanoparticles as fertilizers for increasing agronomic productions", Science of the Total Environment, Vol. 514, pp.131-139.

Liu, Y., Zhang, M., Meng, Z., Wang, B. and Chen, M. (2020), "Research progress on the roles of cytokinin in plant response to stress", International Journal of Molecular Sciences, Vol. 21 No. 18, pp. 6574.

López-Vargas, E. R., González-García, Podsędek, A. (2007), "Natural
Y., Pérez-Álvarez, M., CadenasPliego, G., González-Morales, S., Benavides-Mendoza, A., Cabrera, R. I. and Juárez-Maldonado, A. (2020), "Seed priming with carbon nanomaterials to modify the germination, growth, and antioxidant status of tomato seedlings", Agronomy, Vol. 10 No. 5, Article No. 639.

Martínez-Ballesta, M. C., Zapata, L., Chalbi, N., and Carvajal, M. (2016), "Multiwalled carbon nanotubes enter broccoli cells enhancing growth and water uptake of plants exposed to salinity", Journal of Nanobiotechnology, Vol. 14 No. 1, Article No. 42.

Mok, D. W. S. and Mok, M. C. (2001), "Cytokinin metabolism and action", Annual Review of Plant Physiology and Plant Molecular Biology, Vol. 52, pp. 89-118.

Mukherjee, A., Majumdar, S., Servin, A. D., Pagano, L., Dhankher, O. P. and White, J. C. (2016), "Carbon nanomaterials in agriculture a critical review", Frontiers in Plant Science, Vol. 7, pp. 172.

Patel, J., Lama, L., Hoffmann, N. A., Cobo, J., Müller, C. W. and Ryan, K. (2017), "RNA polymerase III initiation on coligo DNA templates containing loops of variable sequence, size and nucleotide chemistry", Gene, Vol. 612, pp. 4954. 
antioxidants and antioxidant capacity of Brassica vegetables a review", LWT - Food Science and Technology, Vol. 40, pp. 1-11.

Rivero, R. M., Kojima, M., Gepstein, A., Sakakibara, H., Mittler, R., Gepstein, S. and Blumwald, E. (2007), "Delayed leaf senescence induces extreme drought tolerance in a flowering plant", Proceedings of the National Academy of Sciences of the United States of America, Vol. 104 No. 49, pp. 19631-19636.

Sakakibara, H. (2006), "Cytokinins activity biosynthesis and translocation", Annual Review of Plant Biology, Vol. 57, pp. 431-449.

Sakamoto, T., Sakakibara, H., Kojima, M., Yamamoto, Y., Nagasaki, H., Inukai, Y., Sato, Y. and Matsuoka, M. (2006), "Ectopic expression of Knotted1-like homeobox protein induces expression of cytokinin biosynthesis genes in rice", Plant Physiology, Vol. 142, pp. 54-62.

Salisbury, F. B. and Ross, C. W. (1990), Plant physiology, $4^{\text {th }}$ ed., Wadworth Publication Co. Inc. Belmont, California.

Siddiqui MH.; Al Whaibi MH.; Firoz M.; et al. (2015). "Role of nano particles in plants", Nanotechnology and Plant Sciences, Siddiqui M. H. et al. (ed.), Springer International Publishing, Switzerland.

Siddiqui, M. H. and Al-Whaibi, M. H. (2014), "Role of nano- $\mathrm{SiO}_{2}$ in germination of tomato (Lycopersicum esculentum Mill.)", Saudi Journal of Biological Sciences, Vol. 21 No. 1, pp. 13-17.

Siddiqui, M. W., Bhattacharjya, A., Chakraborty, I. and Dhua, R. S. (2011), "Benzylaminopurine improves shelf life, organoleptic quality and health promoting compounds of fresh cut broccoli florets", Journal of Scientific and Industrial Research, Vol. 70 No. 6, pp. 461-465.

Siddiqui, M. W., Singh, J. P., Nayyer Barman K., Ahmad, M. S. and Kumar, V. (2015), "6Benzylaminopurine affects lipid peroxidation and membrane permeability and there by preserves curd quality and antioxidants during storage of cauliflower", Acta Physiologica Plantarum, Vol. 37, Article No. 96.

Srivastava, A. and Handa, A. K. (2005), "Hormonal regulation of tomato fruit development: a molecular perspective", Journal of Plant Growth Regulation, Vol. 24, pp. 67-82.

Stampoulis, D., Sinha, S. K. and White, J. C. (2009), "Assay-dependent phytotoxicity of nanoparticles to plants", Environmental Science \& Technology, Vol. 43 No. 24, pp. 9473-9479.

Stern, R. A., Ben-Arie, R., Neria, O. and Flaishman, M. (2003), "CPPU and BA increase fruit size of 'Royal 
Gala' (Malus domestica) apple in a warm climate", Journal of Horticultural Science and Biotechnology, Vol. 78, pp. 297302.

Taha, R. A. (2016), "Nanotechnology and its application in agriculture", Advances in Plants \& Agriculture Research, Vol. 3 No. 2, Article No. 00089.

Taha, R. A., Hassan, M. M., Ibrahim, E. A., Abou Baker N. H. and Shaaban, E. A. (2016), "Carbon nanotubes impact on date palm in vitro cultures", Plant Cell, Tissue and Organ Culture, Vol. 127 No. 2, pp. 525-534.

Takei, K., Sakakibara, H. and Sugiyama, T. (2001), "Identification of genes encoding adenylate isopentenyltransferase, a cytokinin biosynthesis enzyme, in Arabidopsis thaliana", Journal of Biological Chemistry, Vol. 276, pp. 2640526410.

Takei, K., Yamaya, T. and Sakakibara, H. (2004), "Arabidopsis CYP735A1 and CYP735A2 encode cytokinin hydroxylases that catalyze the biosynthesis of trans-Zeatin", Journal of Biological Chemistry, Vol. 279, pp. 41866-41872.

Talebi, S. M. (2018), Nanoparticleinduced morphological responses of roots and shoots of plants, Elsevier Inc., Cambridge, MA, USA.

Tan X. M., Lin, C. and Fugetsu, B.
(2009), "Studies on toxicity of multi-walled carbon nanotubes on suspension rice cells", Carbon, Vol. 47 No. 15 , pp. 3479-3487.

Tan, X. M. and Fugetsu B. (2007), "Multi-walled carbon-nanotubes interact with cultured rice cells evidence of a self-defense response", Journal of Biomedical Nanotechnology, Vol. 3, pp. 285288.

Verhoeven, D. T., Goldbohm, R. A., van Poppel, G., Verhagen, H. and van den Brandt, P. A. (1996), "Epidemiological studies on Brassica vegetables and cancer risk", Cancer Epidemiology, Biomarkers \& Prevention, Vol. 5, pp. 733-748.

Werner, T., Motyka, V., Laucou, V., Smets, R., Van Onckelen, H. and Schmülling, T. (2003), "Cytokinin deficient transgenic Arabidopsis plants show multiple developmental alterations indicating opposite functions of cytokinins in the regulation of shoot and root meristem activity", The Plant Cell, Vol. 15, pp. 2532-2550.

Werner, T.; Köllmer, I., Bartrina, I., Holst, K. and Schmülling, T. (2006), "New insights into the biology of cytokinin degradation", Plant Biology, Vol. 8, pp. 371-381.

Younes, N. A., Dawood, M. F. and Wardany, A. A. (2019), "Biosafety assessment of graphene nanosheets on leaf ultrastructure, physiological 
and yield traits of Capsicum annuum L. And Solanum melongena L.", Chemosphere, Vol. 228, Article No. 318327.

Yun, L., Mingjing, Z., Zhe, M., Baoshan, W. and Min, C. (2020),"Research progress on the roles of cytokinin in plant response to stress", International Journal of Molecular Sciences, Vol. 21, Article No. 6574.
Zabadal, T. J. and Bukovac, M. J. (2006), "Effect of CPPU on fruit development of selected seedless and seeded grape cultivars", HortScience, Vol. 41, pp. 154-157. 